NBER WORKING PAPER SERIES

GETTING CARS OFF THE ROAD:

THE COST-EFFECTIVENESS OF AN EPISODIC POLLUTION CONTROL PROGRAM

\author{
Maureen L. Cropper \\ Yi Jiang \\ Anna Alberini \\ Patrick Baur \\ Working Paper 15904 \\ http://www.nber.org/papers/w15904 \\ NATIONAL BUREAU OF ECONOMIC RESEARCH \\ 1050 Massachusetts Avenue \\ Cambridge, MA 02138 \\ April 2010
}

We thank the USEPA for funding and Elena Safirova and Winston Harrington for helpful suggestions regarding the paper. We also thank Abe Martin whose Honors Thesis also used this survey data. The views expressed herein are those of the author and do not necessarily reflect the views of the National Bureau of Economic Research.

NBER working papers are circulated for discussion and comment purposes. They have not been peerreviewed or been subject to the review by the NBER Board of Directors that accompanies official NBER publications.

(C) 2010 by Maureen L. Cropper, Yi Jiang, Anna Alberini, and Patrick Baur. All rights reserved. Short sections of text, not to exceed two paragraphs, may be quoted without explicit permission provided that full credit, including (C) notice, is given to the source. 
Getting Cars Off the Road: The Cost-Effectiveness of an Episodic Pollution Control Program Maureen L. Cropper, Yi Jiang, Anna Alberini, and Patrick Baur

NBER Working Paper No. 15904

April 2010

JEL No. Q52,Q53,Q58

\begin{abstract}
$\underline{\text { ABSTRACT }}$
Ground-level ozone remains a serious problem in the United States. Because ozone non-attainment is a summer problem, episodic rather than continuous controls of ozone precursors are possible. We evaluate the costs and effectiveness of an episodic scheme that requires people to buy permits to drive on high-ozone days. We estimate the demand function for permits based on a survey of 1,300 households in the Washington, DC, metropolitan area. Assuming that all vehicle owners comply with the scheme, the permit program would reduce volatile organic compounds (VOCs) by 50 tons and nitrogen oxides (NOx) by 42 tons per Code Red day at a permit price of $\$ 75$. Allowing for non-compliance by 15 percent of respondents reduces the effectiveness of the scheme to 39 tons of VOCs and 33 tons of NOx per day. The cost per ozone season of achieving these reductions is approximately \$9 million (2008 USD). This compares favorably with permanent methods of reducing VOCs that cost $\$ 645$ per ton per year.

Maureen L. Cropper

Department of Economics

University of Maryland

College Park, MD 20742

and NBER

cropper@econ.umd.edu

Yi Jiang

Asian Development Bank

yijiang@adb.org

Anna Alberini

Dept. of Agriculture \& Resource Econ.

University of Maryland

2200 Symons Hall, Campus Drive

College Park, MD 20742

aalberini@arec.umd.edu

Patrick Baur

The National Academies

PBaur@nas.edu
\end{abstract}




\section{Getting Cars Off the Road: \\ The Cost-Effectiveness of an Episodic Pollution Control Program}

Maureen L. Cropper, Yi Jiang, Anna Alberini, and Patrick Baur

\section{INTRODUCTION}

While such major air pollutants as sulfur dioxide and particulate matter are substantially under control, many areas of the United States remain in non-attainment of the ground-level ozone standard. Indeed, 322 of the 675 counties that monitor ozone are currently in violation of the standard. ${ }^{3}$ This includes the counties that make up the Washington Metropolitan Area. ${ }^{4}$ Non-attainment poses a serious public health problem because ozone has significant and well-established adverse effects on the respiratory system (U.S. EPA 2003).

Because ozone non-attainment is a seasonal problem, it is possible to employ episodic rather than continuous control of ozone precursors. Ozone is formed when oxides of nitrogen $\left(\mathrm{NO}_{\mathrm{x}}\right)$ and volatile organic compounds (VOCs) react in the atmosphere. High temperature and sunlight facilitate the process. As a result, peak ozone levels typically occur on hot, sunny days from May to September. Seasonality implies that implementing episodic controls could well be cheaper than requiring investments that remain in place year round, even during seasons when $\mathrm{NO}_{\mathrm{x}}$ and VOCs are unlikely to react to form ozone.

One form that episodic controls might take is to reduce driving on summer days when ozone levels are predicted to be high. Motor vehicles are estimated to account for 56 percent of $\mathrm{NO}_{\mathrm{x}}$ and 45 percent of VOC emissions nationwide (U.S. EPA 2003). In addition, the environmental-engineering literature suggests that controls on mobile sources could be more effective than controls on stationary sources for certain areas. Episodic automobile emissions-control programs do exist in some areas. Previous research, however, has documented that these programs have little success in keeping vehicles off the road on high-ozone days because they are all implemented on a voluntary basis.

The purpose of this study is to examine the cost-effectiveness and feasibility of an episodic control scheme under which people would not be allowed to drive during predicted ozone episodes unless they purchase a permit before the ozone season begins. On-road vehicles failing to display the permit would be subject to a fine. Such a scheme is expected to be more effective than voluntary schemes because it incorporates an incentive for people to restrict driving on high-ozone days. It also might be cheaper than schemes requiring installation of additional capital equipment

\footnotetext{
3 "E.P.A. Seeks Stricter Rules to Curb Smog." New York Times. January 8, 2010.

${ }^{4}$ According to the U.S. Environmental Protection Agency (EPA), the area consists of the District of Columbia; Montgomery, Prince George’s, Frederick, Calvert, and Charles counties in Maryland; and Arlington, Fairfax, Loudoun, Prince William, and Stafford counties and Alexandria City of Virginia. This definition differs from the Census definition of the Washington Metropolitan Statistical Area.
} 
on vehicles or factories.

This paper measures the cost of this scheme by estimating the permit demand curve for the Washington Metropolitan Area. A stated-preference approach is used, based on a survey of more than 1,300 Washington-area commuters. The survey asked each respondent whether he would purchase a permit to drive on high-ozone days during the ozone season, for each vehicle owned, at a stated price. The permit price was varied among respondents to trace out the demand curve for permits. We use the responses to this question to determine the cost associated with a given emissions-reduction requirement, forecast what types of vehicles will be taken off the road, and assess the cost-effectiveness of the scheme (i.e., the cost per ton of emissions reduced). The study also allows us to investigate political acceptability of the scheme and the distribution of costs among income groups.

We focus on the Washington Metropolitan Area for three main reasons. First, like other densely populated urban areas of the United States, the Washington Metropolitan Area has long suffered from severe ozone problems. On average, the ozone level exceeded the U.S. Environmental Protection Agency's (EPA) eight-hour standard on 16.7 days each year from 2001 to 2009. The benefits of effective ozone control should be significant to the residents in the area. Second, the fact that the Washington area has a VOC-limited ozone regime, implying that reductions in VOCs are needed to reduce ambient ozone, favors restricting automobile emissions rather than controlling stationary sources. Third, the existing public transportation system in the area makes it possible to substitute alternative travel modes for driving. Although the project is specific to the Washington Metropolitan Area, our study provides insights into the feasibility and cost-effectiveness of similar programs in other ozone non-attainment regions.

Briefly, we find that the demand for permits (i.e., the probability of purchasing a permit for a vehicle during the ozone season) is negatively related to the price of the permit. All else the same, the demand for permits increases with miles driven, especially when a vehicle accounts for a large share of the total miles driven by a household, and is higher for newer vehicles. Drivers with small children are more likely to buy permits, all else the same, but income, race, and ethnicity are not important, suggesting that this scheme is not regressive. Even at low permit prices (e.g., \$75 for the ozone season), the scheme would reduce VOC emissions by 39-50 tons on a high-ozone day, depending on whether we allow for non-compliance (and little or no enforcement effort) or assume full compliance.

The remainder of the paper is organized as follows. Section II describes the nature and cost of ozone regulations in the United States, briefly reviews the literature on voluntary episodic controls of ozone precursors, and describes the theoretical constructs relevant for such schemes. Section III describes our study design and sampling frame. We describe the characteristics of our sample households and the vehicles they own in section IV, which also presents raw data on permit 
demand. In section $\mathrm{V}$, we present econometric estimates of permit demand and calculate the cost and effectiveness of the program. Section VI concludes.

\section{REGULATORY CONTEXT AND LITERATURE REVIEW}

Colorless and odorless, ground-level ozone is a key component of urban smog and has deleterious effects on human health (U.S. EPA 2003). It can cause severe damage to lung tissue, reduce lung function, and sensitize lungs to other irritants. Individuals who engage in outdoor physical activity (such as children) or persons who have preexisting respiratory diseases are at greater risk from exposure to ozone. In addition to the adverse effects on human health, ozone reduces agricultural and commercial forest yields and increases tree and plant susceptibility to disease, pests, and other environmental stresses.

Ozone is one of the six major air pollutants for which the U.S. EPA sets National Ambient Air Quality Standards. EPA first introduced an ambient ozone standard in 1979 by setting a daily maximum one-hour average ozone level. Studies later found that adverse health effects occur at levels lower than the 1979 standard and that exposure times longer than one hour are also of concern. In July 1997, EPA proposed replacing the one-hour primary ozone standard with a new eight-hour standard to better protect the public from ozone. Attainment of the standard requires the 3-year average of the annual 4th-highest daily maximum 8-hour concentrations be less than or equal to the standard. The 8-hour standard was set at $0.08 \mathrm{ppm}$ in 1997 and revised to $0.075 \mathrm{ppm}$ in 2008. The Washington Metropolitan Area has been designated by EPA as an 8-hour ozone non-attainment area since the 1997 standard was phased in. ${ }^{5}$ Table 1 shows the monthly distribution of ozone exceedance days for the Washington Metropolitan Area from 2001 to 2009. On average during this period, ozone exceedance days numbered 16.7 per ozone season. Note that exceedance days are concentrated in June, July, and August, when the temperature and intensity of sunlight are greatest.

To battle the urban ozone problem, federal and state governments have adopted a variety of strategies, including reducing $\mathrm{NO}_{\mathrm{x}}$ emissions from power plants and industrial combustion sources; encouraging the use of cleaner fuels, including reformulated gasoline; improving transit systems; and implementing vehicle inspection programs. Despite these efforts, many regions-particularly major cities - still fail to meet the ozone standard. One explanation lies in the dramatic increase in the number of cars on the road and the miles they travel. Total vehicle miles traveled (VMT) rose by 36 percent from 1990 to 1999 in the Washington Metropolitan Area and are predicted to rise by 10 percent between 2002 and 2009 (MWCOG 2007).

The environmental engineering literature suggests that controls on mobile sources could be more effective than controls on stationary sources for certain areas (Heuss et al. 2003). According

\footnotetext{
${ }^{5}$ The area was also designated as a one-hour ozone non-attainment area before the eight-hour ozone standard took effect.
} 
to U.S. EPA's National Air Quality and Emissions Trends reports, such major U.S. cities as Los Angeles, San Francisco, and Washington, DC, are VOC-limited - that is, the ratio of VOCs to $\mathrm{NO}_{\mathrm{x}}$ is very low. $\mathrm{NO}_{\mathrm{x}}$ reductions in these areas essentially raise the ratio of VOCs to $\mathrm{NO}_{\mathrm{x}}$ to a level promoting ozone formation. Therefore, VOC-limited areas will benefit from a disproportionate reduction in VOCs (Heuss et al. 2003). Since the dominant source of VOCs is often motor vehicles burning gasoline, rather than stationary sources, some researchers suggest that the least costly and most effective means of reducing ozone under a VOC-limited regime may be to reduce emissions from light-duty gasoline vehicles (Fujita et al. 2003).

The episodic nature of ozone formation favors control measures that are implemented only on high ozone days. Economists have demonstrated that in theory, abating pollution only when pollution episodes are forecast is more economically efficient than undertaking continuous abatement (e.g., Teller 1967; Krupnick 1988). Unfortunately, relatively few studies have empirically examined the effectiveness and cost-effectiveness of episodic programs. Lutter (1999), however, notes that the cost of reducing precursor emissions through conventional measures is very high, when correctly calculated. For example, if the cost of reducing one ton of VOCs over the course of a year through year-round control measures is $\$ 10,000$, this is equivalent to an annual cost of $\$ 3.65$ million to reduce VOCs by one ton each day, as would be required to reduce VOCs by one ton per day during the ozone season.

Local governments have implemented episodic emissions-control programs targeting mobile sources in a number of regions, including Northern and Southern California, Atlanta, and the Baltimore/Washington metropolitan areas. However, the voluntary nature of these programs raises concerns about their effectiveness. Henry and Gordon (2003) and Cummings and Walker (2000), using survey data and traffic counts data, respectively, examine whether people drive less in the Atlanta Metropolitan Area on the expected high-ozone days. Neither study provides convincing evidence that the program effectively reduces driving. Jiang (2009) shows that ozone alerts only resulted in a slight decline in morning inbound and evening outbound traffic in the Baltimore area. Cutter and Neidell (2009) study how people respond to high-ozone alerts in the San Francisco Bay Area. They find that "Spare the Air" announcements reduce total daily traffic by 2.5-3.5 percent, with the largest effects during and just after the morning commuting periods, but have a negligible effect on subway ridership. The authors conclude that voluntary programs of this kind are unlikely to result in improvement in air quality.

Existing evidence demonstrating the ineffectiveness of voluntary programs suggests the need for a permit scheme that provides sufficient incentives for people to forgo driving. People who are not seriously inconvenienced by switching to another mode of travel are unlikely to pay to drive, whereas those who cannot switch easily or who value driving privileges highly will buy a permit. Driving without a permit will be effectively deterred if accompanied by monitoring and enforcement. The critical economic questions are whether a permit system produces sufficient emissions reductions (and thus prevents high-ozone episodes from occurring) and whether it does 
so in a cost-effective way.

The total emissions reductions and the cost of reducing ozone through a permit scheme depend on the shape of the demand function for permits. At the margin, the permit price should equal the value of driving forgone. The demand function for permits thus represents the marginal value of not driving. For a given supply of permits, the cost of reducing ozone precursor emissions can be approximately calculated as the area under the permit demand curve to the right of quantity of permits purchased (area A in Figure 1). To determine the emissions reductions associated with this cost, one must know the characteristics and annual mileage of vehicles for which permits would be bought at that price.

In this paper, we survey residents of the Washington, DC, metro area, asking them whether they would buy permits at a given price in the presence of a no-driving scheme. The price of the permit is varied across respondents. We use the responses to these hypothetical questions to trace out the demand for permits, compute how many vehicles would stay off the road on a high-ozone day, and calculate the cost to the vehicle owner/driver.

\section{STUDY DESIGN}

The data used to evaluate an episodic ozone control program for the Washington metropolitan area come from a survey of 1,312 area commuters conducted in January-March 2008 by Abt SRBI International. In this section, we briefly describe the questionnaire and its administration and our sampling frame.

\section{A. The Questionnaire}

The survey instrument collected information on household demographics, vehicle ownership and usage, and willingness to pay for a permit to drive on high ozone days. We developed the first draft of the questionnaire following the framework of the Nationwide Personal Transportation Survey, with an added section regarding local air quality and the hypothetical permit program. Thereafter, the questionnaire was subject to multiple revisions through focus groups and one-on-one in-depth interviews (see Appendix A).

The final questionnaire consisted of five sections. The beginning section asked screening questions to identify a valid respondent: a household head (or the spouse of a household head) 18 or older who had a valid driver's license, drove at least a few days a month, and was a member of a household that owned at least one vehicle. ${ }^{6}$ It also collected basic information on the number of household members and number, make, and model year of vehicles the household owned.

\footnotetext{
${ }^{6}$ Our sampling plan required an even number of men and women; hence the respondent could be either the head of household or the spouse of the head of household.
} 
The second section surveyed each vehicle owned by the household in detail, up to a maximum of three vehicles. For households owning more than three vehicles we asked about the three vehicles driven most often. ${ }^{7}$ For each vehicle, we collected information on type, fuel type, mileage, miles driven within the past 12 months or since being purchased, and its primary purpose. Depending on the main use of the vehicle, we asked about the average number of days it was driven for this purpose each week, one-way distance driven, presence of a second passenger, and the destination to which it was driven (city or zip code). The respondent was also asked to name the household member who primarily drives the vehicle and provide information on his or her relationship to the respondent, employment situation, ability to work from home, and difficulty of substituting public transportation for driving.

The third section briefly asked about the respondent's perceptions of local air quality, his perceived impact of air pollution on household members' health, his familiarity with smog alerts (Code Red warnings), and his estimation of the number of Code Red days in $2007 .{ }^{8}$

The fourth section began by describing air pollution in the Washington area, its adverse effect on health, and the predictability of bad air quality days. Before describing the permit program, the interviewer stated, "One way to reduce air pollution on these days is to ban the use of personal vehicles, except in emergencies. This would reduce harmful emissions.” Then, the respondent was asked how he would get around if driving were banned on a bad air quality day. In particular, he was asked how likely he would be to work (stay) at home, take public transportation, take a taxicab, bicycle/walk, or drive anyway.

The interviewer then introduced the permit program: "Now, suppose the government were to issue a limited number of permits to allow people to drive on bad air quality days. These permits would be for sale in April and would allow people to drive on all bad air quality days during the summer. People found driving without a permit on a bad air quality day would be issued a ticket. This would result in a fine and points on their driver's license. The revenues from selling permits and from fines would be used to improve public transportation in order to reduce harmful emissions. ... If you bought a permit you would receive a decal to display on your windshield. The decal could not be transferred from one car to another. ..." The respondent was also informed that "Although the total number of bad air quality days that will occur is not known when the decal is purchased, we do have some information about previous years. The average number of bad air quality days for the past five years has been 14 days per year.”

A permit price was presented to the respondent, who was asked whether he would purchase a permit at this price for each vehicle owned. The permit price was randomly selected from six

\footnotetext{
${ }^{7}$ About 7 percent of households in the final sample owned more than three vehicles and were therefore affected by this rule.

${ }^{8}$ Code Red days are days that are forecast to be high-ozone days. The hypothetical permit scheme would require a vehicle to have a permit in order to be driven on a Code Red day.
} 
candidate prices ranging from $\$ 75$ to $\$ 1,000 .^{9}$ The interviewer asked people who would not buy any permits why and how likely they would be to do the following on the bad air quality days: work (stay) at home, carpool with someone who had purchased a permit, take public transportation or a taxicab, bicycle/walk, or drive without a permit. We also asked how likely the driver of one vehicle not covered by the permit would be to choose each of these options on bad air quality days.

The last section collected information about household demographic and housing characteristics, income, residence location, as well as the proximity of household to various public transportation facilities.

\section{B. Survey Administration and Sampling Frame}

Abt SRBI conducted pretests and implemented the survey (see Appendix A) via telephone. The survey began on January 29, 2008, and finished on March 9, 2008, with 1,203 completed households. The response rate, defined as completes plus screen-outs divided by all eligible phone numbers called, and the cooperation rate, defined as completes plus screen-outs divided by eligible households excluding non-contact and unknown households, ${ }^{10}$ are 0.159 and 0.331 , respectively. After removing the 306 screen-outs, the ratios of completed interviews to all eligible numbers called and eligible numbers excluding non-contact and unknown households are 0.127 and 0.264, respectively. Since 109 of the second round of 180 pretests (see Appendix A) shared the same survey instrument as the final survey, we pooled them with the final survey sample together to enlarge the sample size to 1,312 usable interviews.

To better capture the geographical distribution of vehicle ownership in the survey, we designed a simple sampling framework in combination with random-digit dialing. Using 2000 Census micro data, ${ }^{11}$ we calculated the share of each county-level jurisdiction within the survey region in terms of number of households owning at least one vehicle. The survey sample was required to mimic this distribution. Table 2 reports the distribution of the pooled sample across jurisdictions and the corresponding shares obtained from the 2000 Census. It shows that implementation of the sampling framework was quite successful. The biggest gap occurred in Fairfax County, VA, where about 16 households were oversampled. Figure 2 maps the locations of these respondents.

\footnotetext{
${ }^{9}$ See Table 7 for the exact amounts.

${ }^{10}$ The denominator is the sum of completes, screen-outs, partial interviews, refusals and break-offs, and others.

11 This is the latest data set available that allows us to do the calculation. It is plausible to think that the distribution has not changed dramatically since 2000 .
} 


\section{HOUSEHOLD AND VEHICLE DATA}

\section{A. Characteristics of Sample Households and Their Vehicles}

Table 3 describes the characteristics of our 1,312 survey respondents. The target population was heads of household or their spouses over 18 years old who drive to work and own at least one vehicle. Respondents ranged in age from 18 to 91, with an average age of 49. Fifty-three percent of respondents were female. Sixty-seven percent of respondents were white, 21 percent black, and 6 percent Hispanic. $^{12}$

The economic and educational status of respondents reflects the fact that Washington, DC, is an affluent metropolitan area. Eighty-one percent of respondents owned their own homes. Respondents were highly educated: 65 percent had a bachelor's degree or better, and 32 percent had a graduate degree. Twenty-one percent of respondents refused to disclose their household income. Of those who did report this information, 63 percent had household incomes of $\$ 80,000$ or higher, and 26 percent had incomes of \$150,000 of higher. Thirty-eight percent of households owned one vehicle, 41 percent two vehicles, 14 percent three vehicles, and 7 percent four or more vehicles. Vehicle ownership by our households matches closely data from the 2006 American Community Survey. With regard to other household characteristics, it is difficult to obtain distributions of income and education conditional on car ownership.

Tables 4 and 5 describe the characteristics of vehicles owned by the households in our sample. Sixty-one percent of the vehicles owned by households are cars; 37 percent are SUVs or other light-duty trucks. Twenty-seven percent of vehicles are model year 2005 or more recent; 61 percent are 2001 or more recent. Average annual miles driven (11,900 per year) correspond closely to the national average. More than half of the vehicles (54 percent) are used primarily for commuting to work, 22 percent primarily for running errands, 5 percent to go to school, and 5 percent to drive to public transportation. Table 5 describes the joint distribution of miles driven and vintage. On average, newer cars are driven more miles than older cars.

Table 6 describes the VOC and $\mathrm{NO}_{\mathrm{x}}$ emissions of the vehicles in our sample. Vehicle emissions of the common air pollutants (in grams per mile) depend, among other factors, on the type of vehicle (car, truck, motorcycle), fuel used (gasoline or diesel), and model year. We have matched emissions factors (grams/mile) for $\mathrm{NO}_{\mathrm{x}}$, VOCs, carbon monoxide, and particulate matter from Mobile 6 (Davidson 2009) to the vehicles in our dataset based on these criteria. Emissions factors are estimates for the year 2010 and cover model years 1986-2008. Multiplying each vehicle's emissions by miles driven provides an estimate of total emissions per vehicle per year. Although miles driven are higher for more recent model years, these cars are also cleaner. As a result, the average grams of pollutant emitted per year increases with vehicle vintage. For example,

\footnotetext{
${ }^{12}$ The questionnaire was administered in Spanish as well as English.
} 
the average VOCs emitted by vehicles in the 1986-1993 vintage category are 16 times the emissions of vehicles in the 2005-2008 vintage category.

\section{B. Scenario Acceptance and Raw Data on Permit Purchases}

Table 7 presents raw data on permit purchases, as a function of permit price. Only 5 out of 1,312 respondents refused to answer the permit-demand question, while 48 were uncertain whether they would purchase a permit. We have coded both "Don't Know" and "Refused” as not buying a permit. The percent of cars for which a permit is purchased declines monotonically as a function of permit price: 48 percent of vehicles are covered by a permit at a price of $\$ 75$, falling to 16 percent at a price of $\$ 1,000$.

We asked respondents who stated they would not purchase a permit why they would not and found that 14.4 percent of households objected to the permit scheme on principle. Four percent of respondents objected to the government interfering with their right to drive; 2 percent objected to the program as another form of taxation. Some respondents believed that the program favored the rich (about 2 percent), while 2 percent believed that it was inappropriate to sell the right to drive. We also asked respondents what they would do on a Code Red day if they did not have a permit. Approximately 15 percent of respondents said they would be "very likely" or "somewhat likely" to drive anyway. We term these individuals non-compliant. ${ }^{13}$

Who are people who would not comply with the permit scheme? Table B.1 in Appendix B presents estimates of a probit model to explain non-compliant respondents. Briefly, (stated) non-compliance is more likely among those respondents who live far away from public transportation and among persons with less than a graduate degree or some graduate education (the omitted education category). The latter effect is more pronounced for respondents with a high-school degree or some college than for college graduates, which may reflect less flexibility in the respondent's work schedule. Income, race, and ethnicity are not associated with (stated) non-compliance, and even the price of a permit is only weakly associated with (stated) non-compliance.

In the next section we first estimate permit demand based on all respondents, including non-compliers. These results are used to evaluate the cost-effectiveness of the scheme assuming full compliance. (In this scenario the non-compliant buy no permits and are assumed to stay off the road on high-ozone days.) We then estimate permit demand, eliminating people who say they would not comply with the permit scheme. If the permit scheme does not apply to those respondents who would not buy a permit and continue driving without a permit (15 percent of the total respondents, or 16 percent of the vehicles covered by our survey), then it would be possible to attain emissions reductions only from the remainder of the vehicle fleet (84 percent of the

\footnotetext{
${ }^{13}$ Only 40 percent of people who made verbal statements about the program said they would drive without a permit. We believe that the latter statement is the appropriate measure of non-compliance.
} 
vehicles).

\section{ECONOMETRIC ESTIMATES OF PERMIT DEMAND}

\section{A. Econometric Model}

We posit that an individual will buy a permit for vehicle $j$ at the stated price if the utility of driving that vehicle on a Code Red day is greater that the utility of not driving it, even though the permit costs money. Formally, the individual will buy the permit for vehicle $\mathrm{j}$ if

$$
U(\text { driving }, y-P)>U(\text { not driving }, y) \text {, }
$$

where $y$ is income and $P$ permit price. This is equivalent to stating that the individual buys the permit if his or her willingness to pay for it is greater than the price of the permit. The probability of purchasing a permit for vehicle $\mathrm{j}$ is thus:

$$
\operatorname{Pr}\left(\text { Permit }_{i j}\right)=\operatorname{Pr}\left(W T P_{i j}^{*}>P_{i j}\right),
$$

where $i$ denotes the individual and $W T P^{*}$ is the unobserved willingness to pay for a permit.

We further assume that $W T P_{i j}^{*}=\exp \left(\mathbf{x}_{i} \boldsymbol{\beta}+\mathbf{z}_{i j} \gamma\right) \cdot \exp \left(\varepsilon_{i j}\right)$, where $\mathbf{x}$ is a vector of individual or household characteristics, $\mathbf{z}$ is a vector of vehicle characteristics, and $\varepsilon$ is an econometric error term, implying that

$$
\operatorname{Pr}\left(\text { Permit }_{i j}\right)=\operatorname{Pr}\left(\mathbf{x}_{i} \boldsymbol{\beta}+\mathbf{z}_{i j} \gamma+\varepsilon_{i j}>\ln P_{i j}\right) .
$$

We assume that the marginal distribution of $\varepsilon$ is a zero-mean normal. However, we wish to allow for the possibility that unobserved factors within a household affect all permit purchase decisions

for that household. In other words, $\varepsilon_{i j}=v_{i}+\eta_{i j}$, where $v$ is a normally distributed zero-mean variate and $\eta$ is an independently and identically distributed error with mean zero and variance one. Both $v$ and $\eta$ are uncorrelated with $\mathbf{x}$ and $\mathbf{z} ; v$ and $\eta$ are also independent of one another. It follows from these assumptions that $\varepsilon$ is correlated across the vehicles within a household (the correlation coefficient being $\operatorname{Var}(v) /(1+\operatorname{Var}(v))$ but independent across households. This results in a random-effects probit model.

\section{B. The Effect of Permit Price on Demand}

Table 8 presents the results of random-effects probit regressions where we suppress $\mathbf{x}$ and $\mathbf{z}$, and the only regressor is the log of the permit price. Panels A-D differ only in that specific observations were excluded from the sample as indicated to check the robustness of the results. Comparison of panel A with panel B implies that it is reasonable to treat a failure to answer the 
permit question as a "no," whereas panels C and D imply that the estimated coefficients are very stable to excluding vehicles for which we do not know the mileage or the model year. As shown in the table, the coefficient on the log of the permit price is always negative and significant, as expected, and the estimates for the different runs are extremely close to one another.

As shown in Figure 3, which is based on run A, the model does a very good job of predicting the actual relative frequencies of the purchases at any given permit price. Figure 3 also confirms that it is appropriate to enter the log of the permit price (as opposed to the price) in the probit model.

\section{B. The Impact of Vehicle and Household Characteristics on Permit Demand}

Economic theory suggests that the higher the cost of not driving a vehicle, the greater the chance that the respondent will buy a permit at the stated price. Individuals should be more likely to buy permits for vehicles that they drive more frequently, account for a larger share of the miles driven by the household, and are used primarily for commuting or as part of someone's job, or when there are few or no public transportation alternatives. We also believe that individuals with heavy family demands, and especially those with small children, will find it more difficult to substitute an alternative mode of transportation for driving and will therefore be more likely to purchase a permit.

Based on these considerations, we fit several specifications of the random-effects probit models. ${ }^{14}$ We report specifications that include vehicle characteristics (miles driven, vintage, type of vehicle, and driving purpose) in Table 9. Specifications that check whether individual or household characteristics influence the decision to purchase a permit are displayed in Table 10. Table 9 shows that, given the price, the likelihood of buying a permit increases monotonically with the number of miles a vehicle is driven each year (conditional on knowing annual mileage). This effect is strong and robust across specifications. The effect of the model year is more difficult to interpret. Respondents are more likely to buy permits if their vehicles belong to any one of the four indicated vintage categories (1986-1993, 1994-2000, 2001-2004, and 2005-2008) than to the reference group (pre-1986). The coefficients on the dummy variables for these vintage categories are large, but they are estimated imprecisely and suggest a non-monotonic relationship between the age of the vehicle and the probability of a permit purchase. The larger the share of the total driving within the household that is accounted for by this particular vehicle, the more likely is the respondent to purchase a permit for this vehicle. The coefficient on this variable is large (about 0.60 ) and strongly statistically significant, with p-values on the order of $10^{-5}$ or smaller.

\footnotetext{
${ }^{14}$ To preserve model comparability, all models are estimated using the set of 2,233 vehicles, with indicator variables used to capture the effects of missing data.
} 
To get a sense of the magnitude of the above effects, we created four hypothetical vehicle "profiles." Profiles 1 and 2 are vehicles driven less than 10,000 miles a year, with model years in the 1986-1993 and 1994-2000 categories, respectively. Profiles 3 and 4 are vehicles driven more than 15,000 miles a year that belong to the 2001-2004 and 2005-2008 model year categories, respectively. In each case, we assume that the vehicle accounts for 61 percent of the total miles driven within the household (the sample average). Under these assumptions, if we set the permit price at $\$ 100$, the predicted probability of purchasing a permit is 31.8 percent for profile 1 and 42.4 percent for profile 2-a large increase. At higher miles driven, and with a newer vehicle, the likelihood of purchasing the permit at the same price is 59.6 percent for profile 3 , and 56.3 percent for profile 4 .

Specifications B-D show that ease of access to public transportation and the specific type of vehicle (whether it is a car, a pickup truck, a van, or a sport utility vehicle) do not have a statistically significant impact on the decision to purchase a permit. We measure the impact of public transportation in two ways. One is to ask how easy it would be for the main driver of each vehicle to use public transportation rather than drive the vehicle. For 13 percent of the drivers, it would be "very easy"; for 26 percent, either "very easy" or "somewhat easy." The second is to ask how far the household is from a bus stop, the Metro, or a MARC commuter train. Approximately 70 percent of households are within a mile of a bus or Metro stop. Neither variable has a statistically significant effect on permit demand, although their coefficients have negative signs. Model D suggests that households are no more likely to buy a permit for a car, pickup truck, van, or SUV than for a recreational vehicle or motorcycle (the omitted category).

Specifications C and D, however, suggest that use patterns matter. For example, respondents are more likely to buy a permit for vehicles that are driven to work, for work (e.g., by a plumber or carpenter), or to school—all of which are presumably regarded as non-discretionary travel.

In Table 10, we report the results of specifications that examine the effect of individual and household characteristics on the likelihood of purchasing a permit. The impact of sociodemographic variables on permit demand is clearly of interest for policy purposes; however, household income and respondent education and gender have no statistically significant effect on permit purchase. Because income affects vehicle ownership and miles driven, we estimate a set of models that exclude these variables. Income in the survey was recorded in a series of intervals. We have modeled income as a series of dummy variables and also as a continuous variable equal to the midpoint of the reported interval. Models A and B report the impact of log(income) on permit demand, controlling for gender, presence of young children in the household, and race. Although income is positively related to permit demand, it is never significant at the conventional levels. Models B and C add respondent education to the model. Respondents with a high school education or less appear more likely to purchase permits than respondents with a graduate degree or some graduate training (the omitted category), but this, too, is not significant at the conventional levels. Respondent gender has no effect on permit demand. 
The only demographic variables that appear to affect permit demand are race and the presence of small children in the household. Whites are significantly less likely to purchase a permit (holding income and education constant) than Blacks and the omitted group (Asians and Native Americans). We also find that among the respondents who did provide information about the composition of their household, those respondents who have small children are more likely to purchase a permit at any price.

\section{Calculating the Cost and Effectiveness of the Permit Scheme}

To predict the number of cars that will not be driven under the scheme and the resulting reduction in vehicle emissions, we need to know how permit demand varies with vehicle emissions. We focus here on VOC emissions; however, we obtained similar results for $\mathrm{NO}_{\mathrm{x}}$ emissions. When permit demand is estimated as a function of annual VOC emissions per vehicle and the log of permit price, annual VOC emissions have no statistically significant effect on demand - either linearly or when interacted with permit price. (This is also true for $\mathrm{NO}_{\mathrm{x}}$ emissions.) Although vehicle owners are more likely to purchase permits for cars that are newer and driven more miles, new cars are substantially cleaner than older cars, even when the older cars are driven fewer miles (see Table 6). Thus, from the perspective of predicting the reduction in vehicle emissions, we can ignore vehicle characteristics and focus on permit demand as a function of permit price alone.

To predict the reduction in miles driven and the cost of the permit scheme, we must evaluate the probability of purchasing a permit, as a function of permit price, for prices below $\$ 75$ - the lowest price offered in the survey. ${ }^{15}$ Table 11 shows the predicted probability of purchasing a permit for a randomly chosen vehicle, as a function of price, using model A from Table 8 . The aggregate demand for permits is the demand curve in Table 11 multiplied by the number of passenger vehicles in the metropolitan area. According to the National Capital Region Transportation Planning Board (2006), approximately 2.0 million passenger vehicles and 1.2 million light-duty trucks were registered in the Washington Metropolitan Area as of June 1, 2005; hence, we treat the number of vehicles as 3.2 million. $^{16}$

What is the cost of the episodic control scheme? Table 11 implies that free permits would cover virtually all vehicles. Raising permit price to $\$ 75$ would reduce the percent of vehicles covered by approximately 44 percent. ${ }^{17}$ The lost consumer surplus associated with a permit price of $\$ 75$ for each vehicle not driven is the shaded area in Figure 1. Assuming 14 Code Red days per season, the opportunity cost of getting each vehicle off the road is $\$ 0.614$ per day. Multiplying this by the number of vehicles removed $(0.44 * 3.2$ million), implies a welfare cost per Code Red day of

\footnotetext{
${ }^{15}$ Because demand is a function of $\ln$ (permit price), the lowest price used is $\$ 1$.

${ }^{16}$ The exact numbers are 2,004,089 passenger vehicles and 1,180,563 light duty trucks (National Capital Region Transportation Planning Board 2006).

${ }^{17}$ It should be noted that not all registered vehicles in the metropolitan area are driven every day. We account for this by calculating VOC emissions based on the average miles driven per day.
} 
approximately $\$ 863,000 .^{18}$

How would this affect emissions? Multiplying the number of vehicles removed by average daily tailpipe emissions implies that a permit price of $\$ 75$ per season would reduce emissions on a Code Red day by 49.6 tons of VOCs, 42.2 tons of $\mathrm{NO}_{\mathrm{x}}$, 552.5 tons of carbon monoxide and 0.231 tons of particulate matter. This implies a cost per ton of VOCs abated of approximately $\$ 17,400$ per Code Red day. Raising permit price above $\$ 75$ would further reduce emissions but would significantly increase the cost per ton of VOCs reduced (see Table 11).

Of course, the episodic control scheme also would raise revenue. At a price of $\$ 75$, the sale of permits would raise approximately $\$ 119$ million in revenue. In addition to reducing VOCs, the scheme would have benefits in terms of reduced traffic congestion and reductions in other pollutants.

\section{The Cost of the Scheme with Less than Full Compliance}

The calculations presented in previous sections assume 100 percent compliance, as is usual when examining the impact of proposed regulations. However, about 15 percent of our respondents said that if the permit program were enacted, they would be "very" or "somewhat" likely to drive without a permit. In this section we examine program cost-effectiveness figures under an alternate scenario-one with less than full compliance and no (or limited) enforcement effort. If the permit scheme does not apply to those respondents who would ignore the program and continue driving without a permit (15 percent of the respondents, or 16 percent of the vehicles in our survey), then it would be possible to attain emissions reductions only from the remainder of the vehicle fleet (84 percent of the vehicles).

When we exclude from the sample those respondents who insisted that they would continue driving without a permit, the likelihood of purchasing a permit is higher at any given permit price. To illustrate, at $\$ 75$, the fraction of vehicles that would be covered by a permit is 47.66 percent for the full sample and 54.21 percent for the “compliant” sample. At higher prices, the percentage of vehicles covered by a permit is about 4-6 percentage points higher in the compliant sample than in the full sample. Permits priced at \$1,000 would cover 18.03 percent of the compliant respondents’ vehicles, compared to 16 percent for the full sample. We note, for the purpose of calculating emission reductions, that excluding the non-compliant respondents leaves the average annual emissions of $\mathrm{NO}_{\mathrm{x}}$ and VOCs virtually unchanged.

A random-effects probit model of the responses from the compliant owners confirms that at any given price, the likelihood of purchasing a permit is greater than for the full sample. The slope

\footnotetext{
${ }^{18}$ This ignores the revenue implications of the scheme and tax interaction effects. Permit revenues should equal approximately $\$ 119$ million per season at a permit price of $\$ 75$.
} 
of the demand function with respect to permit price, however, is similar. ${ }^{19}$ When we include driving patterns and characteristics of the vehicle in the random-effects probit models, the results (displayed in Appendix B, Table B.2) are, for the most part, similar to those of the models for the full sample in Table 9. The decision to purchase a permit appears to depend in virtually the same fashion on the log of the permit price and the miles driven but is somewhat less strongly associated with the model year of the vehicle. One difference between the two sets of results is the impact of vehicle type: cars and pickup trucks are more likely to be covered by a permit in the compliant sample than in the full sample.

The impacts of sociodemographic variables on permit purchase (displayed in Appendix B, Table B.3 for the non-compliant sample) are similar for the two samples: income has no statistically significant impact on permit purchase, but respondents with young children are more likely to purchase a permit. Whites are less likely to purchase a permit than non-whites, all else equal. One difference between the two samples is the effect of education. In the compliant sample, respondents whose highest level of education is a high school degree (or less) are more likely to purchase a permit relative to persons with some graduate education, and the effect is significant at the 5-percent level.

Using the basic random-effects probit with no covariates, we predict the number of vehicles that would not be driven under the permit scheme (out of 3,200,000*0.84=2,688,000 eligible vehicles), the associated emissions reductions, cost per ton of VOCs, and cost of the total emissions reductions attained per day (Table 12).

On the basis of a cost per ton of VOCs, the two programs are virtually identical. However, less than full compliance clearly limits the emissions-reduction potential of the episodic control scheme. For example, at a permit price of \$75, only 38.6 tons of VOCs would be reduced each day, against the 50 tons achieved under a full-compliance scenario. Still, at a cost of $\$ 9$ million for a 14-day high ozone season, the episodic control program remains attractive when compared to conventional controls. Using the $\$ 5,000$ cost per annul ton of VOCs reduced, the total cost for the same reduction in VOCs (38.6 tons) would be $\$ 70$ million. ${ }^{20}$

\section{CONCLUSIONS}

The primary goal of this study is to evaluate the cost-effectiveness of a vehicle permit scheme compared to other methods of controlling ozone precursors. Ozone in Washington, DC, is VOC-limited, implying that the goal is to reduce emissions of VOCs on what are predicted to be high-ozone days. The welfare cost of the scheme is approximated by the area under the demand curve for permits to the right of the quantity of permits issued (Figure 1). We estimated this cost

\footnotetext{
${ }^{19}$ When the full sample is used, the estimated coefficients from a random-effects probit are 1.818256 (intercept) and -0.425366 (coefficient on log bid). The compliant sample results in a larger intercept (1.997979) and a virtually identical slope (-0.4290023).

${ }^{20}$ Standard errors for all key measures of the accomplishments of the program are based on the approach described in Krinsky and Robb 1986.
} 
based on a survey of more than 1,300 Washington-area commuters conducted in 2008. Our calculations suggest that a permit price of $\$ 75$ per season would remove approximately 44 percent of cars and light-duty trucks from the roads on high-ozone days, assuming full compliance with the scheme, and 34 percent of passenger vehicles, allowing for non-compliance. Focusing on the non-compliance scenario and assuming 14 high-ozone days in an average summer, the program would cost approximately $\$ 648,000$ per day in lost consumer surplus and would result in approximately 38.6 fewer tons of VOCs emitted per day, at a cost of $\$ 16,800$ per ton of VOCs removed per high-ozone day. The program would also raise approximately $\$ 111$ million in revenue per ozone season, which could be used to defray administrative costs. ${ }^{21}$ Raising permit price above \$75 would increase the effectiveness of the scheme but would also raise the cost per ton of VOCs removed, due to the steepness of the demand curve for permits.

How does the cost of the episodic scheme compare with the cost of year-round controls? In 2004, the U.S. EPA declared the Washington, DC, region in moderate non-attainment of the eight-hour ozone standard (U.S. EPA 2004). The Metropolitan Washington Council of Governments (MWCOG) submitted a plan outlining steps to make reasonable progress toward attainment over the 2002-2009 period (MWCOG 2007). One goal was to reduce VOCs by 87 tons per day (from the 2002 baseline) by 2009. Most reductions were to come from reduced emissions from non-road engines under the federal non-road gasoline and diesel rules. Although the cost of individual control options is not specified, MWCOG (2007) describes an economically feasible control strategy as one with a cost of $\$ 5,000$ per ton of VOCs per year or less. The U.S. EPA (2008), in its Regulatory Impact Analysis for the National Ambient Air Quality Standard for Ozone, also capped the cost of reducing VOCs at \$5,000 per ton per year. ${ }^{22}$ This corresponds to a cost of $365 * \$ 5,000$ to reduce a ton of VOCs every day, or $\$ 70.4$ million annually to meet the 38.6 ton reduction delivered by the episodic control program at just $\$ 9$ million. This suggests that a program such as described here could be a cost-effective way of reducing ozone precursors on high-ozone days.

Another way to compare the cost of the episodic program with the cost of year-round controls is to convert the cost of the episodic control scheme into the cost of an equivalent year-round scheme. If the cost of reducing a ton of VOCs over the course of a year were $\$ 645$ (instead of $\$ 5,000$ ) it would cost $\$ 645 * 365=\$ 235,000$ to reduce a ton of VOCs every day. The cost of meeting the 38.6 ton reduction would be $\$ 9.07$ million - the cost of the episodic program. So, the episodic control program is equivalent to a program of permanent controls costing $\$ 645$ per ton of VOC reduced per year.

Concerns may arise about the possible regressivity of the episodic control scheme. It appears from our estimates, however, that such a scheme is not regressive. The demand for permits is not

\footnotetext{
${ }^{21}$ In the full compliance scenario, 55 percent of compliant vehicles would be covered by a permit at a price of $\$ 75$.

${ }^{22}$ The U.S. EPA notes that this cost will not be sufficient to achieve the proposed, stricter ozone standard.
} 
significantly related to income and/or education, although non-whites appear to be more likely to purchase a permit. Finally, it should be noted that the scheme is progressive to the extent that people who do not own a car (who are likely to be poor) will benefit from air quality improvements while bearing none of the scheme's costs. 


\section{REFERENCES}

Cutter, W. Bowman, and Matthew Neidell. 2009. Voluntary Information Programs and Environmental Regulation: Evidence from "Spare the Air." Journal of Environmental Economics and Management 58(3): 253-65.

Cummings, R. G., and M. B. Walker. 2000. Measuring the Effectiveness of Voluntary Emission Reduction Programmes. Applied Economics 32(13): 1719-26.

Davisdon, Kenneth. 2009. Personal communication between Kenneth Davidson, Economist, USEPA , and the authors. January 13, 2009.

Fujita, E. M., D.E. Campbell, B. Zielinska, J.C. Sagebiel, J.L. Bowen, W.S. Goliff, W.R. Stockwell, and D.R. Lawson. 2003. Diurnal and Weekday Variations in the Source Contributions of Ozone Precursors in California's South Coast Air Basin. Journal of Air and Waste Management Association 53(7): 844-63.

Henry, G. T., and C. S. Gordon. 2003. Driving Less for Better Air: Impacts of a Public Information Campaign. Journal of Policy Analysis and Management 22(1): 45-63.

Heuss, J. M., D. F. Kahlbaum, and G. T. Wolff. 2003. Weekday/Weekend Ozone Differences: What Can We Learn from Them? Journal of Air and Waste Management Association 53(7): 772-88.

Jiang, Yi. 2009. Do People Drive Less on Code Red Days? Mimeo. Manila, Philippines: Asian Development Bank.

Krinsky, I., and A. L. Robb. 1986. On Approximating the Statistical Properties of Elasticities. Review of Economic and Statistics 68(4): 715-19.

Krupnick, A. J. 1988. Temporal and Spatial Control of Ambient Ozone. Discussion paper QE88-05. Washington, DC: Resources for the Future.

Lutter, Randall. 1999. Is EPA’s Ozone Standard Feasible? Working paper 99-6. Washington, DC: AEI-Brookings Joint Center for Regulatory Studies.

MWCOG (Metropolitan Washington Council of Governments). 2007. Plan to Improve Air Quality in the Washington, DC-MD-VA Region: State Implementation Plan (SIP) for Fine Particle $\left(P M_{2.5}\right)$ Standard and 2002 Base Year Inventory for the Washington DC-MD-VA Nonattainment Area. Washington, DC: MWCOG. 
National Capital Region Transportation Planning Board. 2006. The Composition of Vehicle Fleet in the Washington Metropolitan Region. Mimeo. Washington, DC: MWCOG.

Teller, A. 1967. Air Pollution Abatement: Economic Rationality and Reality. Daedalus, 96(4): 1082-98.

U.S. EPA (Environmental Protection Agency). 2003. Ozone: Good Up High, Bad Nearby. 451/K-03-001. Washington, DC: EPA.

. 2004. The Ozone Report: Measuring Progress through 2003. 454/K-04-001.

Washington, DC: EPA

. 2008. Final Ozone NAAQS Regulatory Impact Analysis. 452/R-08-003. Washington,

DC: EPA. 
Figure 1. Demand for Permits and the Total Cost of the Scheme

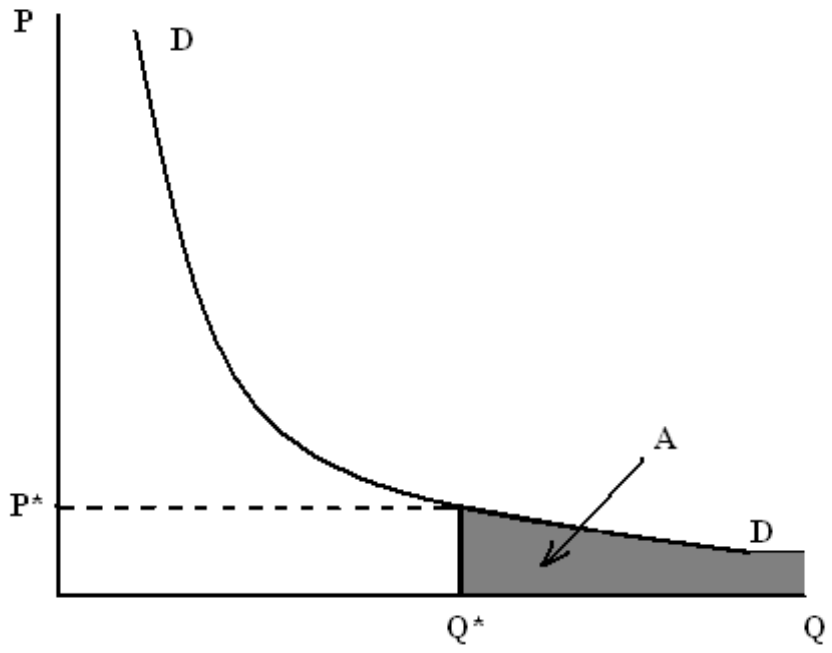

Note: The cost of a scheme in which permit price $=\mathrm{P}^{*}$ and emissions $=\mathrm{Q}^{*}$ is the shaded area $\mathrm{A}$. 
Figure 2. Locations of Survey Respondents by Area of Residence

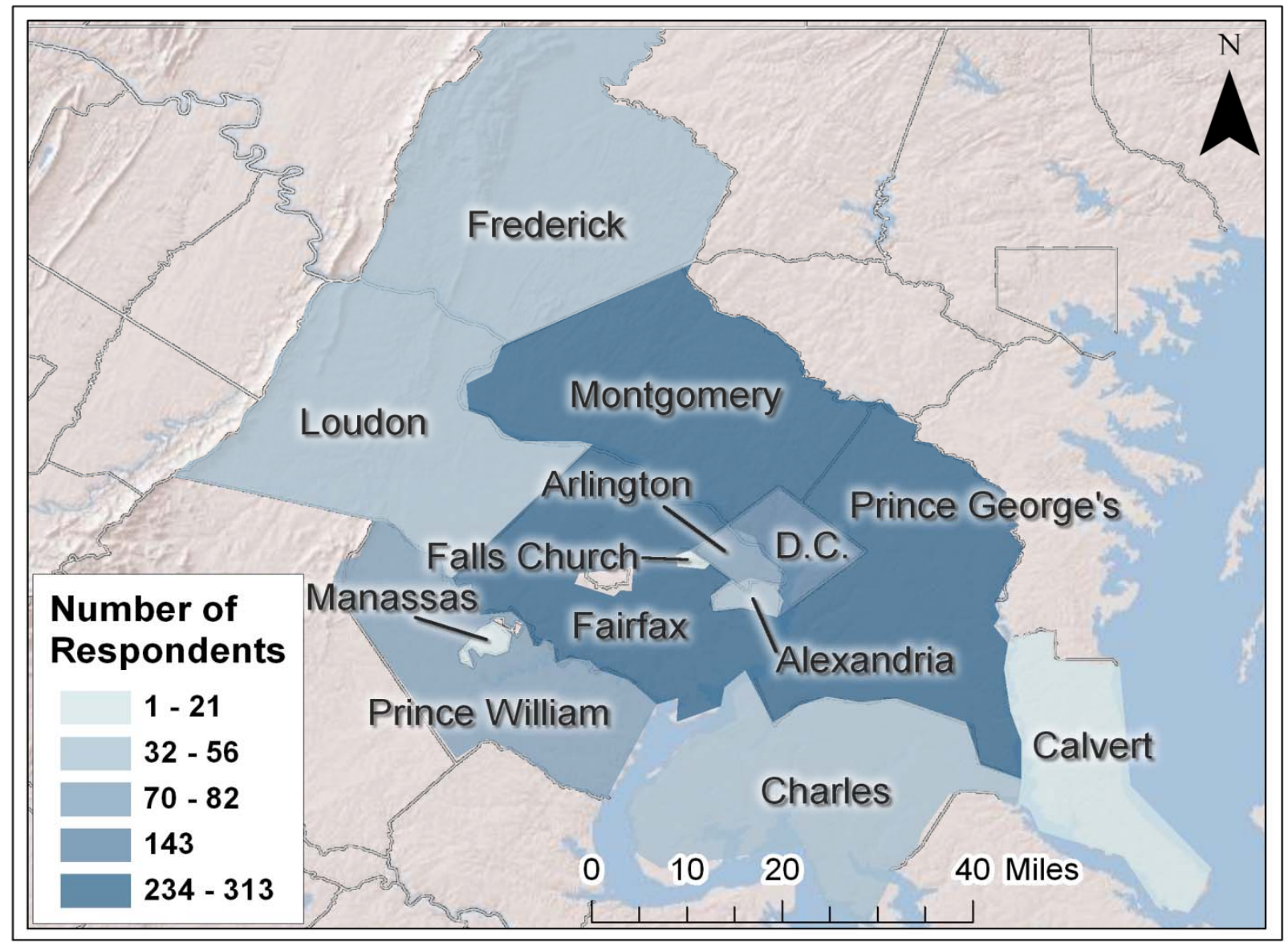


Figure 3. Actual and Predicted Probability of Purchasing a Permit

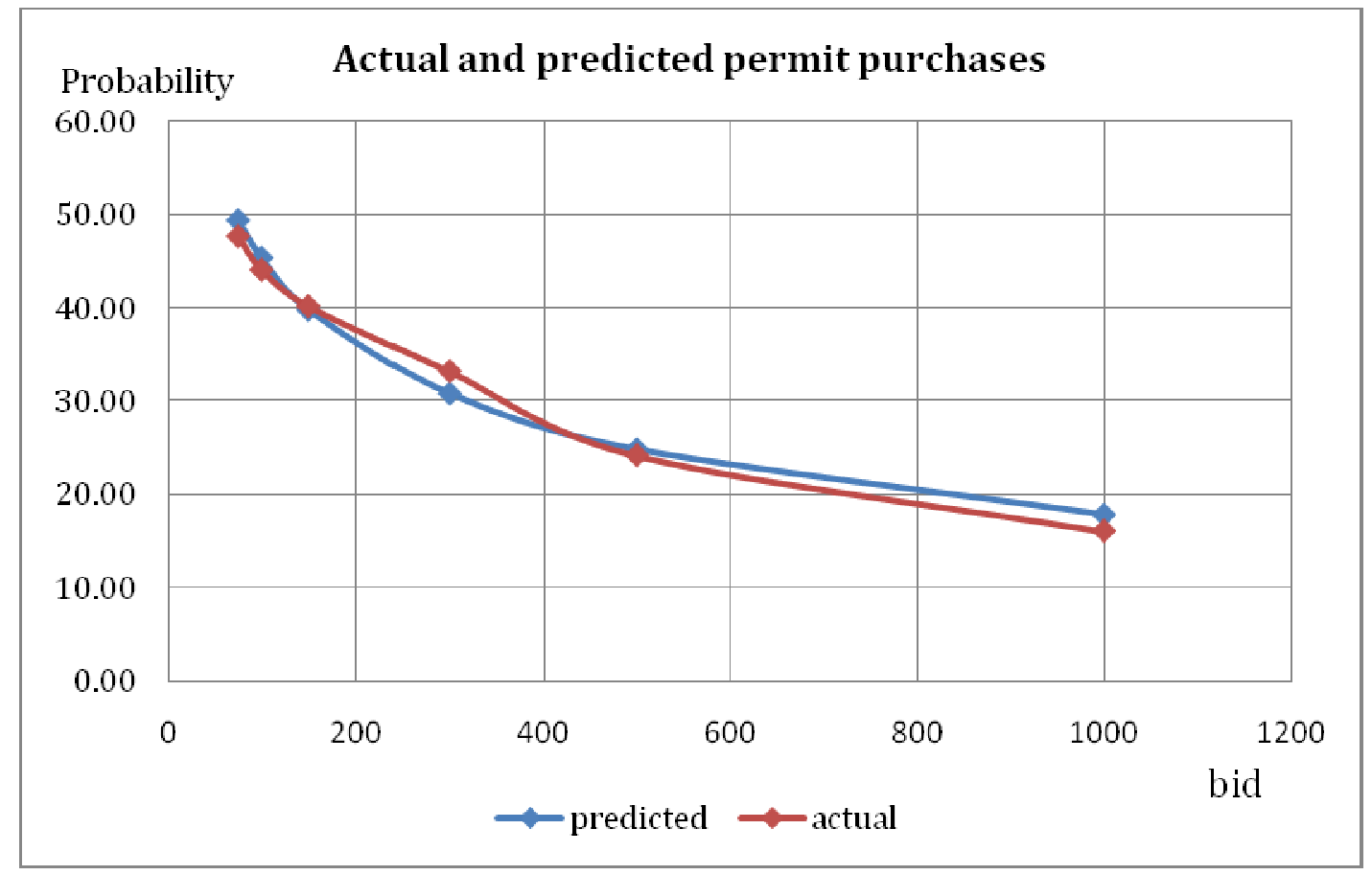


Table 1. Distributions of Ozone Exceedance Days in the Metropolitan Washington Area

\begin{tabular}{ccccccc}
\hline Year & May & June & July & August & September & Total \\
\hline 2001 & 6 & 10 & 2 & 6 & 0 & 24 \\
2002 & 0 & 8 & 15 & 13 & 2 & 38 \\
2003 & 0 & 4 & 0 & 3 & 0 & 7 \\
2004 & 1 & 1 & 3 & 2 & 0 & 7 \\
2005 & 0 & 3 & 6 & 8 & 1 & 18 \\
2006 & 3 & 4 & 5 & 7 & 0 & 19 \\
2007 & 3 & 2 & 3 & 6 & 2 & 16 \\
2008 & 0 & 6 & 6 & 3 & 2 & 17 \\
2009 & 0 & 3 & 0 & 1 & 0 & 4 \\
Total & 13 & 41 & 40 & 49 & 7 & 150 \\
\hline
\end{tabular}

Source: Authors' summary based on daily data prepared by Department of Environmental Programs, Metropolitan Washington Council of Governments, Washington, DC. 
Table 2. Survey Households and Households Owning Vehicles in the 2000 Census by Washington Metropolitan Area Jurisdiction

\begin{tabular}{lccc}
\hline \multirow{2}{*}{ District/county/city } & \multicolumn{2}{c}{ Survey } & Regional \% of households with \\
\cline { 2 - 3 } vehicle(s) in 2000 Census
\end{tabular}


Table 3. Descriptive Statistics of Survey Respondents

\begin{tabular}{|c|c|c|c|c|c|}
\hline Variable & Number & Pronortion (\%) & & & \\
\hline \multicolumn{6}{|l|}{ Gender $(n=1.312)$} \\
\hline Women & 701 & 53.4 & & & \\
\hline Men & 611 & 46.6 & & & \\
\hline \multicolumn{6}{|l|}{ Race or ethnicity $(n=1,312)$} \\
\hline White & 847 & 64.6 & & & \\
\hline Black & 368 & 20.4 & & & \\
\hline Hispanic & 78 & 5.9 & & & \\
\hline \multicolumn{6}{|l|}{ Hiqhest level of education $(n=1,291)$} \\
\hline High school or less & 151 & 11.7 & & & \\
\hline Some college & 190 & 14.7 & & & \\
\hline Associate’s degree & 117 & 9.1 & & & \\
\hline Bachelor’s degree & 326 & 25.3 & & & \\
\hline Some graduate school & 89 & 6.9 & & & \\
\hline Graduate degree & 418 & 32.4 & & & \\
\hline \multicolumn{6}{|c|}{ Household annual income $(n=1,042)$} \\
\hline$<20 \mathrm{k}$ & 25 & 2.4 & & & \\
\hline $20 \mathrm{k}-40 \mathrm{k}$ & 86 & 8.3 & & & \\
\hline $40 \mathrm{k}-60 \mathrm{k}$ & 147 & 14.1 & & & \\
\hline $60 \mathrm{k}-80 \mathrm{k}$ & 131 & 12.6 & & & \\
\hline $80 \mathrm{k}-100 \mathrm{k}$ & 152 & 14.6 & & & \\
\hline $100 \mathrm{k}-150 \mathrm{k}$ & 226 & 21.7 & & & \\
\hline $150 \mathrm{k}-200 \mathrm{k}$ & 135 & 13.0 & & & \\
\hline$>200 \mathrm{k}$ & 140 & 13.4 & & & \\
\hline Variable & Number & Mean & Std. dev. & Min. & Max. \\
\hline Respondent age & 1.240 & 49 & 14.7 & 18 & 91 \\
\hline Household size (number of people) & 1,285 & 2.65 & 1.52 & 1 & 11 \\
\hline Number of children age 7-17 & 1,286 & 0.48 & 0.88 & 0 & 5 \\
\hline Number of children age 6 and under & 1,286 & 0.28 & 0.64 & 0 & 4 \\
\hline Number of employed persons & 1,268 & 1.55 & 0.86 & 0 & 5 \\
\hline Number of drivers & 1,289 & 1.95 & 0.80 & 0 & 5 \\
\hline Number of vehicles & 1,312 & 1.95 & 1.02 & 1 & 10 \\
\hline Estimated Code Red days per year & 894 & 11.7 & 12.7 & 1 & 100 \\
\hline
\end{tabular}

Note: Std. dev. = standard deviation. 
Table 4. Descriptive Statistics of the Vehicles

\begin{tabular}{lccccc}
\hline Variable & Number & Mean & Std. dev. & Min. & Max. \\
\hline Vehicle model year & 2,207 & 2001 & 5.2 & 1953 & 2008 \\
Odometer reading (in 10,000 miles) & 2,052 & 7.48 & 7.20 & 0.0001 & 98 \\
$\quad$ Miles driven in last 12 months (in & 1,970 & 1.19 & 1.25 & 0.0001 & 12 \\
$\quad$ 10,000 miles) & & & & & 7 \\
$\begin{array}{l}\text { Average days per week car driven } \\
\quad \text { for primary purpose }\end{array}$ & 2,173 & 4.52 & 1.54 & 1 & \\
\hline Variable & Number & Proportion (\%) & & \\
\hline Purpose for which vehicle is primarily driven & & & \\
To work & 2,233 & 54.1 & & \\
To public transportation & 2,233 & 4.5 & & \\
To school & 2,233 & 4.6 & & & \\
For work (plumber, carpenter, etc.) & 2,233 & 2.8 & & & \\
For errands & 2,233 & 22.7 & & & \\
For recreation & 2,233 & 6.4 & & & \\
Vehicle type & & & & \\
Cars & 2,233 & 61.0 & & \\
SUVs, trucks, and vans & 2,233 & 36.9 & & \\
\hline
\end{tabular}


Table 5. Mileage by Model Year, Number of Observations (Percentage of all vehicles)

\begin{tabular}{lcccccc}
\hline \multirow{2}{*}{ Annual mileage } & \multicolumn{7}{c}{ Vehicle model year } \\
\cline { 2 - 7 } & Pre-1986 & $1986-1993$ & $1994-2000$ & $2001-2004$ & $2005-2008$ & All years \\
\hline$<5,000$ & $13(0.7)$ & $57(2.9)$ & $211(10.8)$ & $158(8.1)$ & $109(5.6)$ & $548(28.0)$ \\
$5,001-10,000$ & $5(0.3)$ & $35(1.8)$ & $192(9.8)$ & $217(11.1)$ & $160(8.2)$ & $609(31.2)$ \\
$10,001-15,000$ & $2(0.1)$ & $15(0.8)$ & $115(5.9)$ & $172(8.8)$ & $122(6.2)$ & $426(21.8)$ \\
$>15,000$ & $3(0.2)$ & $9(0.5)$ & $96(4.9)$ & $123(6.3)$ & $141(7.2)$ & $372(19.0)$ \\
Any mileage & $23(1.2)$ & $116(5.9)$ & $614(31.4)$ & $670(34.3)$ & $532(27.2)$ & $1,955^{\mathrm{a}}$ \\
& & & & & &
\end{tabular}

${ }^{\text {a }} 283$ observations were excluded because data on annual mileage or model year were missing (11 observations were missing both values). 
Table 6. Estimated Annual Volatile Organic Compound (VOC) and Nitrogen Oxide $\left(\mathrm{NO}_{\mathrm{x}}\right)$ Emissions by Vehicle Model Year

\begin{tabular}{lcccccc}
\hline \multirow{2}{*}{ Model year } & \multicolumn{3}{c}{ VOCs (kilograms, $\mathrm{n}=1,860)$} & \multicolumn{3}{c}{$\mathrm{NO}_{\mathrm{x}}$ (kilograms, $\left.\mathrm{n}=1,860\right)$} \\
\cline { 2 - 7 } & Mean & $\begin{array}{c}\text { Standard } \\
\text { deviation }\end{array}$ & Frequency & Mean & $\begin{array}{c}\text { Standard } \\
\text { deviation }\end{array}$ & Frequency \\
\hline Before 1986 & N/A & & & N/A & & \\
$1986-1993$ & 47.7 & 67.7 & 113 & 20.6 & 28.0 & 113 \\
$1994-2000$ & 19.0 & 27.5 & 602 & 16.5 & 18.8 & 602 \\
$2001-2004$ & 5.3 & 5.5 & 651 & 7.5 & 7.5 & 651 \\
$2005-2008$ & 2.9 & 2.9 & 494 & 2.7 & 2.9 & 494 \\
\hline
\end{tabular}


Table 7. Permits Purchased by Price

\begin{tabular}{lcccccc}
\hline Permit price (\$) & 75 & 100 & 150 & 300 & 500 & 1,000 \\
\hline Number of vehicles & 384 & 361 & 376 & 389 & 348 & 375 \\
Number of permits purchased & 183 & 159 & 151 & 129 & 84 & 60 \\
Percent vehicles covered by permits & 47.66 & 44.04 & 40.16 & 33.16 & 24.14 & 16.00 \\
\hline
\end{tabular}


Table 8. Random-Effects Probit Models of Permit Purchase: Basic Model

\begin{tabular}{|c|c|c|c|c|c|c|c|c|}
\hline \multirow{4}{*}{ Variable } & \multicolumn{8}{|c|}{ Sample description } \\
\hline & \multirow{2}{*}{\multicolumn{2}{|c|}{$\begin{array}{c}\text { A } \\
\text { Entire sample, } \\
\text { treating “Don’t } \\
\text { Know" and “Refused" } \\
\text { as “No”" }\end{array}$}} & \multirow{2}{*}{\multicolumn{2}{|c|}{$\begin{array}{c}\text { B } \\
\text { Drop “Don’t Know" } \\
\text { and "Refused” }\end{array}$}} & \multirow{2}{*}{\multicolumn{2}{|c|}{$\begin{array}{c}\text { C } \\
\text { Further drop } \\
\text { observations with } \\
\text { unknown vintage or } \\
\text { mileage }\end{array}$}} & \multirow{2}{*}{\multicolumn{2}{|c|}{$\begin{array}{c}\text { D } \\
\text { Treat “Don’t Know" } \\
\text { and "Refused" as “No," } \\
\text { drop observations with } \\
\text { unknown vintage or } \\
\text { mileage }\end{array}$}} \\
\hline & & & & & & & & \\
\hline & Coefficient & t statistic & Coefficient & t statistic & Coefficient & t statistic & Coefficient & t statistic \\
\hline Constant & 1.81826 & 7.71 & 1.85030 & 7.85 & 1.90323 & 7.64 & 1.87366 & 7.55 \\
\hline $\begin{array}{l}\log \\
\text { (permit } \\
\text { price) }\end{array}$ & -0.42537 & -9.61 & -0.42241 & -9.58 & -0.42877 & -9.18 & -0.43076 & -9.23 \\
\hline Number & 2,233 & - & 2,153 & - & 1,895 & - & 1,955 & - \\
\hline $\log (L)$ & $-1,353.29$ & - & $-1,322.65$ & - & $-1,170.14$ & - & $-1,194.1$ & - \\
\hline
\end{tabular}


Table 9. Random-Effects Probit Models of Permit Purchase: Vehicle Characteristics and Driving Patterns $(\mathrm{N}=2,233)$

\begin{tabular}{|c|c|c|c|c|c|c|c|c|}
\hline \multirow{2}{*}{ Variable } & \multicolumn{2}{|c|}{ Specification A } & \multicolumn{2}{|c|}{ Specification B } & \multicolumn{2}{|c|}{ Specification C } & \multicolumn{2}{|c|}{ Specification D } \\
\hline & Coefficient & t statistic & Coefficient & t statistic & Coefficient & t statistic & Coefficient & t statistic \\
\hline Constant & 0.65397 & 1.50 & 0.67460 & 1.53 & 0.43224 & 0.93 & 0.09282 & 0.18 \\
\hline $\log$ (permit price) & -0.44984 & -9.52 & -0.45173 & -9.54 & -0.46238 & -9.47 & -0.46708 & -9.46 \\
\hline 12-month mileage 5,001-10,000 & 0.23721 & 2.32 & 0.23262 & 2.27 & 0.16081 & 1.52 & 0.17390 & 1.63 \\
\hline 12-month mileage $10,001-15,000$ & 0.50759 & 4.54 & 0.49544 & 4.41 & 0.34554 & 2.99 & 0.36087 & 3.09 \\
\hline 12-month mileage $>15,000$ & 0.67694 & 5.66 & 0.67276 & 5.58 & 0.45073 & 3.61 & 0.46479 & 3.68 \\
\hline 12-month mileage unknown & 0.54764 & 3.59 & 0.56465 & 3.68 & 0.46985 & 2.94 & 0.48452 & 3.01 \\
\hline Model year 1986-1993 & 0.22572 & 0.57 & 0.22815 & 0.58 & 0.11413 & 0.28 & 0.15283 & 0.37 \\
\hline Model year 1994-2000 & 0.57727 & 1.57 & 0.58626 & 1.6 & 0.44954 & 1.18 & 0.48814 & 1.27 \\
\hline Model year 2001-2004 & 0.68288 & 1.85 & 0.68786 & 1.86 & 0.55848 & 1.46 & 0.60163 & 1.56 \\
\hline Model year 2005-2008 & 0.57732 & 1.56 & 0.58389 & 1.57 & 0.46101 & 1.2 & 0.50115 & 1.3 \\
\hline Model year unknown & 0.36178 & 0.73 & 0.38587 & 0.77 & 0.33757 & 0.65 & 0.40165 & 0.77 \\
\hline $\begin{array}{l}\text { Vehicle share of total household 12-month mileage } \\
\text { (\%) }\end{array}$ & 0.59507 & 4.67 & 0.61166 & 4.68 & 0.60183 & 4.44 & 0.58894 & 4.32 \\
\hline Easy for respondent to access public transportation & & & -0.08236 & -0.95 & -0.04656 & -0.52 & -0.05421 & -0.61 \\
\hline Accessibility to public transportation unknown & & & -0.13218 & -0.88 & -0.47672 & -2.01 & -0.45939 & -1.92 \\
\hline Respondent lives within a mile of a bus or metro stop & & & 0.01801 & 0.2 & 0.00311 & 0.03 & 0.00219 & 0.02 \\
\hline Proximity to a bus or metro stop unknown & & & -0.16082 & -0.87 & -0.13258 & -0.7 & -0.12424 & -0.65 \\
\hline Vehicle driven primarily to work & & & & & 0.74793 & 4.95 & 0.73069 & 4.81 \\
\hline Vehicle driven primarily for work & & & & & 1.38815 & 4.1 & 1.35947 & 3.99 \\
\hline Vehicle driven primarily to school & & & & & 0.48019 & 2.24 & 0.46480 & 2.15 \\
\hline Vehicle driven primarily to public transportation stop & & & & & 0.33455 & 1.5 & 0.31179 & 1.39 \\
\hline Vehicle driven primarily for errands & & & & & 0.21192 & 1.33 & 0.20269 & 1.26 \\
\hline Primary vehicle purpose unknown & & & & & -0.33190 & -0.94 & -0.28915 & -0.82 \\
\hline Car & & & & & & & 0.37842 & 1.49 \\
\hline Pickup & & & & & & & 0.31127 & 1.19 \\
\hline SUV & & & & & & & 0.19512 & 0.71 \\
\hline Van & & & & & & & 0.30477 & 1.07 \\
\hline log likelihood & $-1,299.83$ & & $-1,298.64$ & & $-1,262.73$ & & $-1,260.52$ & \\
\hline
\end{tabular}


Table 10. Random-Effects Probit Models of Permit Purchase: Sociodemographic Variables $(\mathrm{N}=2233)$

\begin{tabular}{lcccccc}
\hline \multirow{2}{*}{ Variable } & \multicolumn{2}{c}{ Specification A } & \multicolumn{2}{c}{ Specification B } & \multicolumn{2}{c}{ Specification C } \\
\cline { 2 - 7 } & Coefficient & t statistic & Coefficient & t statistic & Coefficient & t statistic \\
\hline Constant & 1.74924 & 4.4 & 1.60307 & 4.03 & 2.055833 & 7.41 \\
log (permit price) & -0.43148 & -9.79 & -0.43232 & -9.72 & -0.428276 & -9.73 \\
Female & 0.02034 & 0.28 & -0.00386 & -0.05 & 0.014414 & 0.2 \\
log (household annual income) & 0.07552 & 1.18 & 0.04472 & 0.67 & & \\
Household income unknown & 0.25580 & 0.82 & 0.09643 & 0.3 & & \\
Has children age 0-6 & 0.12650 & 2.24 & 0.14327 & 2.53 & 0.134270 & 2.39 \\
Number of children age 0-6 unknown & -0.68520 & -1.93 & -0.67701 & -1.89 & -0.657590 & -1.83 \\
Black & 0.06138 & 0.38 & & & 0.058917 & 0.37 \\
White & -0.37757 & -2.6 & & & -0.360031 & -2.48 \\
Race unknown & -0.41095 & -1.92 & & & -0.404736 & -1.9 \\
Hispanic & -0.03243 & -0.18 & & & -0.053352 & -0.3 \\
Hispanic ethnicity unknown & -0.38278 & -1.06 & & & -0.325815 & -0.89 \\
High school & & & 0.23091 & 1.77 & 0.118137 & 0.96 \\
Some college & & & -0.02453 & -0.21 & -0.117114 & -1.03 \\
Associate's degree & & & 0.15662 & 1.14 & 0.056240 & 0.41 \\
Bachelor's degree & $-1,331.03$ & & -0.01831 & 0.19 & 0.001809 & 0.02 \\
Unknown & & & $-1,341.985$ & & $-1,330.225$ & -1.01 \\
log likelihood & & & & & & \\
\hline
\end{tabular}


Table 11. Cost and Emissions Reductions Associated with the Episodic Ozone Control Program (Standard errors in parentheses)

\begin{tabular}{ccccccc}
\hline $\begin{array}{c}\text { Permit } \\
\text { price } \\
(\$)\end{array}$ & $\begin{array}{c}\text { Vehicles } \\
\text { removed from } \\
\text { road (\%) }\end{array}$ & $\begin{array}{c}\text { Vehicles } \\
\text { removed from } \\
\text { road per day } \\
\text { (millions) }\end{array}$ & $\begin{array}{c}\text { Cost of the program } \\
\text { per high-ozone day } \\
\text { (thousand \$) }\end{array}$ & $\begin{array}{c}\text { Tons of VOCs } \\
\text { reduced per } \\
\text { high-ozone day }\end{array}$ & $\begin{array}{c}\text { Cost per ton of } \\
\text { VOC abated per } \\
\text { day (thousand \$) }\end{array}$ & $\begin{array}{c}\text { Tons of } \mathrm{NO}_{\mathrm{x}} \\
\text { heduced per }\end{array}$ \\
\hline 75 & 43.9 & $1.40(0.04)$ & $863(89)$ & $49.6(1.6)$ & $17.4(1.4)$ & $42.2(1.3)$ \\
100 & 47.9 & $1.53(0.05)$ & $1,324(150)$ & $54.2(1.9)$ & $24.4(2.1)$ & $46.0(1.6)$ \\
150 & 53.5 & $1.71(0.07)$ & $2,318(291)$ & $60.5(2.4)$ & $38.3(3.4)$ & $51.4(2.1)$ \\
300 & 62.5 & $2.00(0.09)$ & $5,477(749)$ & $70.6(3.3)$ & $77.5(7.2)$ & $60.0(2.8)$ \\
500 & 68.5 & $2.19(0.11)$ & $9,661(1325)$ & $77.4(3.9)$ & $124.8(11.3)$ & $65.8(3.3)$ \\
1,000 & 75.5 & $2.42(0.12)$ & $19,289(749)$ & $85.4(4.4)$ & $226.0(18.1)$ & $72.5(3.7)$ \\
\hline
\end{tabular}

Notes: VOCs=volatile organic compounds: $N O_{x}=$ nitrogen oxide 
Table 12. Cost and Emissions Reductions Associated with the Episodic Ozone Control Program, Based on Compliant Drivers (Standard errors in parentheses)

\begin{tabular}{ccccccc}
\hline $\begin{array}{c}\text { Permit } \\
\text { Price } \\
(\$)\end{array}$ & $\begin{array}{c}\text { Vehicles } \\
\text { removed } \\
\text { from road } \\
(\%)\end{array}$ & $\begin{array}{c}\text { Vehicles } \\
\text { removed from } \\
\text { road per day } \\
\text { (millions) }\end{array}$ & $\begin{array}{c}\text { Cost of the } \\
\text { program per } \\
\text { high-ozone day } \\
\text { (thousand \$) }\end{array}$ & $\begin{array}{c}\text { Tons VOCs } \\
\text { reduced per } \\
\text { high-ozone } \\
\text { day }\end{array}$ & $\begin{array}{c}\text { Cost per ton of } \\
\text { VOCs abated } \\
\text { per day } \\
\text { (thousand \$) }\end{array}$ & $\begin{array}{c}\text { Tons of } \mathrm{NO}_{\mathrm{x}} \\
\text { reduced per } \\
\text { high-ozone day }\end{array}$ \\
\hline 75 & 40.7 & $1.09(0.03)$ & $648(59)$ & $38.6(1.07)$ & $16.8(1.2)$ & $32.8(0.9)$ \\
100 & 44.9 & $1.21(0.04)$ & $1,021(105)$ & $42.6(1.26)$ & $24.0(1.9)$ & $36.2(1.1)$ \\
150 & 50.8 & $1.37(0.05)$ & $1,850(218)$ & $48.2(1.66)$ & $38.4(3.4)$ & $41.0(1.4)$ \\
300 & 60.6 & $1.63(0.07)$ & $4,606(617)$ & $57.5(2.42)$ & $80.1(7.6)$ & $48.9(2.1)$ \\
500 & 67.2 & $1.81(0.08)$ & $8,404(1146)$ & $63.8(2.92)$ & $131.7(12.3)$ & $54.2(2.5)$ \\
1,000 & 75.2 & $2.02(0.10)$ & $17,870(2223)$ & $71.4(3.38)$ & $250.4(20.2)$ & $60.6(2.9)$ \\
\hline
\end{tabular}

${ }^{*}$ Based on 84 percent of all eligible vehicles.

Notes: VOCs=volatile organic compounds; $\mathrm{NO}_{x}=$ nitrogen oxide. 
As a first step in designing the survey, the authors arranged four focus groups, comprising 38 Washington-metropolitan residents who drive to work, in Rockville, Maryland; and Vienna and McLean, Virginia. We hired a graduate student from the Program in Survey Methodology of University of Maryland as moderator. The moderator prompted participants to talk about area traffic and their commuting experience, their perceptions of local air quality, and any thoughts about the permit program as described by the moderator. Open-ended questions solicited minimum and maximum willingness to pay for the permit. Consensus existed among the groups that traffic conditions are far from pleasant-and are worse in Northern Virginia than in Maryland. Many participants also linked local air quality (smog) to massive traffic.

While some people appreciated the episodic permit program, others gave frank concerns and opinions about the program. Members of the focus groups commonly raised questions regarding the cost-effectiveness and fairness of the program, the few alternatives available to driving, and use of program revenues. The discussions also touched on many details of program implementation and enforcement. For instance, would medical emergencies be exempted from the permit program? When people were presented with a choice between a decal attached to the windshield and an electronic chip installed in the car, they were inclined to choose the former, as the chip would result in an intruding, "Big Brother” effect. The majority of the stated amounts people would pay for a permit-which allows vehicle owners to drive on 14 days during ozone season (based on historical averages) — ranged from \$10 to \$500. Overall, the focus groups were highly informative and helpful in improving the questionnaire.

Edge Research Inc. then conducted one-on-one in-depth interviews to fine-tune the questionnaire. The firm recruited twelve participants, demographically representative Washington-metropolitan residents who commute by driving. A professional moderator from Edge Research led each participant through the entire questionnaire, making sure that the participant could easily understand and answer all questions. Each interview took between 45 and 60 minutes. After each interview, the moderator briefly discussed the participant's responses to and comments on the questionnaire with the authors, who observed the interview behind a one-way mirror. The questionnaire was then updated in real time. The in-depth interviews helped us adjust the structure of the survey instrument and make its language clearer and more accurate.

We initially intended to administer the survey to 1,500 households, divided into 300 pretest households and a formal sample of 1,200. Abt SRBI Inc. programmed the questionnaire into the CATI (Computer-Assisted Telephone Interviewing) system in early December 2007. A pretest of 120 households was carried out in the middle of December 2007. The authors listened to some of the interviews and decided to further adjust the survey, especially the section on vehicle use. Abt SRBI conducted the remaining 180 pretests between January 16 and January 24, 2008. No additional changes were found necessary. Our final sample thus consisted of 1,200 households 
plus 109 households in the second pretest who received the same design values for permit price as households in the final survey. 


\section{Appendix B.}

Table B.1. Probit Models of People Protesting the Permit Scheme: Demographic Characteristics $(\mathrm{N}=1,312)$

\begin{tabular}{|c|c|c|c|c|c|c|}
\hline \multirow[t]{2}{*}{ Variable } & \multicolumn{2}{|c|}{ Specification A } & \multicolumn{2}{|c|}{ Specification B } & \multicolumn{2}{|c|}{ Specification C } \\
\hline & Coefficient & t statistic & Coefficient & t statistic & Coefficient & t statistic \\
\hline Constant & -2.47524 & 0.619 & -2.30949 & 0.630 & -2.40081 & 0.64 \\
\hline $\log$ (permit price) & 0.08421 & 0.047 & 0.08961 & 0.047 & 0.09197 & 0.05 \\
\hline log (household income) & -0.04736 & 0.080 & -0.04959 & 0.080 & -0.03652 & 0.08 \\
\hline Household income unknown & 0.01540 & 0.375 & 0.02519 & 0.377 & 0.09275 & 0.38 \\
\hline Respondent age & 0.03357 & 0.018 & 0.03447 & 0.018 & 0.03393 & 0.02 \\
\hline Square of respondent age & -0.00038 & 0.000 & -0.00039 & 0.000 & -0.00039 & 0.00 \\
\hline Respondent age unknown & 0.72738 & 0.487 & 0.76847 & 0.489 & 0.72640 & 0.50 \\
\hline Female & -0.09476 & 0.088 & -0.10962 & 0.088 & -0.11450 & 0.09 \\
\hline White & 0.22458 & 0.183 & 0.23130 & 0.184 & 0.24190 & 0.18 \\
\hline Black & 0.09490 & 0.201 & 0.13066 & 0.202 & 0.15519 & 0.20 \\
\hline Race unknown & 0.18782 & 0.251 & 0.17414 & 0.253 & 0.18094 & 0.25 \\
\hline Hispanic & -0.16675 & 0.227 & -0.14071 & 0.228 & -0.12208 & 0.23 \\
\hline Ethnicity unknown & -0.44539 & 0.472 & -0.50918 & 0.475 & -0.62769 & 0.50 \\
\hline Number of vehicles owned by household & 0.08134 & 0.043 & 0.06221 & 0.045 & 0.06511 & 0.04 \\
\hline \multicolumn{7}{|l|}{ Highest education level } \\
\hline High school or less & 0.34591 & 0.152 & 0.33467 & 0.152 & 0.35272 & 0.15 \\
\hline Some college & 0.46153 & 0.134 & 0.47113 & 0.134 & 0.48404 & 0.13 \\
\hline Associate's degree & 0.17335 & 0.167 & 0.14727 & 0.169 & 0.16544 & 0.17 \\
\hline Bachelor’s degree & 0.25441 & 0.114 & 0.25084 & 0.114 & 0.25610 & 0.11 \\
\hline Level of education unknown & 0.46635 & 0.363 & 0.36155 & 0.369 & 0.21381 & 0.39 \\
\hline $\begin{array}{l}\text { Respondent lives within a mile of a bus or } \\
\text { metro stop }\end{array}$ & & & -0.24749 & 0.102 & -0.25058 & 0.10 \\
\hline Proximity to bus or metro stop unknown & & & 0.08192 & 0.192 & 0.07614 & 0.19 \\
\hline Has children age $0-6$ & & & & & 0.00985 & 0.07 \\
\hline Number of children age 0-6 unknown & & & & & 0.59429 & 0.29 \\
\hline log likelihood & -532.55 & & -529.01 & & -527.03 & \\
\hline
\end{tabular}


Table B.2. Random-Effects Probit Models of Permit Purchase: Sociodemographic Variables, Protestors Removed ( $\mathrm{N}=1,876)$

\begin{tabular}{|c|c|c|c|c|c|c|}
\hline \multirow[t]{2}{*}{ Variable } & \multicolumn{2}{|c|}{ Specification A } & \multicolumn{2}{|c|}{ Specification B } & \multicolumn{2}{|c|}{ Specification C } \\
\hline & Coefficient & t statistic & Coefficient & t statistic & Coefficient & t statistic \\
\hline Constant & 1.87109 & 4.61 & 1.56129 & 3.84 & 2.15021 & 7.56 \\
\hline $\log$ (permit price) & -0.43904 & -9.65 & -0.43816 & -9.59 & -0.43751 & -9.64 \\
\hline Female & -0.01520 & -0.20 & -0.03564 & -0.47 & -0.02709 & -0.36 \\
\hline log (household annual income) & 0.07681 & 1.18 & 0.08411 & 1.23 & & \\
\hline Household income unknown & 0.28031 & 0.88 & 0.29776 & 0.89 & & \\
\hline Has children age $0-6$ & 0.13387 & 2.29 & 0.14634 & 2.51 & 0.14264 & 2.45 \\
\hline Number of children age 0-6 unknown & -0.52422 & -1.42 & -0.49612 & -1.34 & -0.49443 & -1.33 \\
\hline Black & 0.18161 & 1.10 & & & 0.15458 & 0.94 \\
\hline White & -0.29619 & -1.99 & & & -0.27573 & -1.85 \\
\hline Race unknown & -0.28069 & -1.30 & & & -0.25884 & -1.2 \\
\hline Hispanic & -0.04478 & -0.24 & & & -0.09640 & -0.52 \\
\hline Hispanic ethnicity unknown & -0.47654 & -1.36 & & & -0.41290 & -1.16 \\
\hline \multicolumn{7}{|l|}{ Highest education level } \\
\hline High school & & & 0.41370 & 3.03 & 0.27058 & 2.11 \\
\hline Some college & & & 0.07429 & 0.62 & -0.02957 & -0.25 \\
\hline Associate’s degree & & & 0.25678 & 1.85 & 0.13801 & 0.99 \\
\hline Bachelor's degree & & & 0.09159 & 0.96 & 0.07065 & 0.74 \\
\hline Unknown & & & -0.33044 & -0.93 & -0.32154 & -0.87 \\
\hline log likelihood & $-1,163.22$ & & $-1,171.06$ & & $-1,160.84$ & \\
\hline
\end{tabular}


Table B.3. Random-Effects Probit Models of Permit Purchase: Vehicle Characteristics and Driving Patterns, Protestors Removed (N=1876)

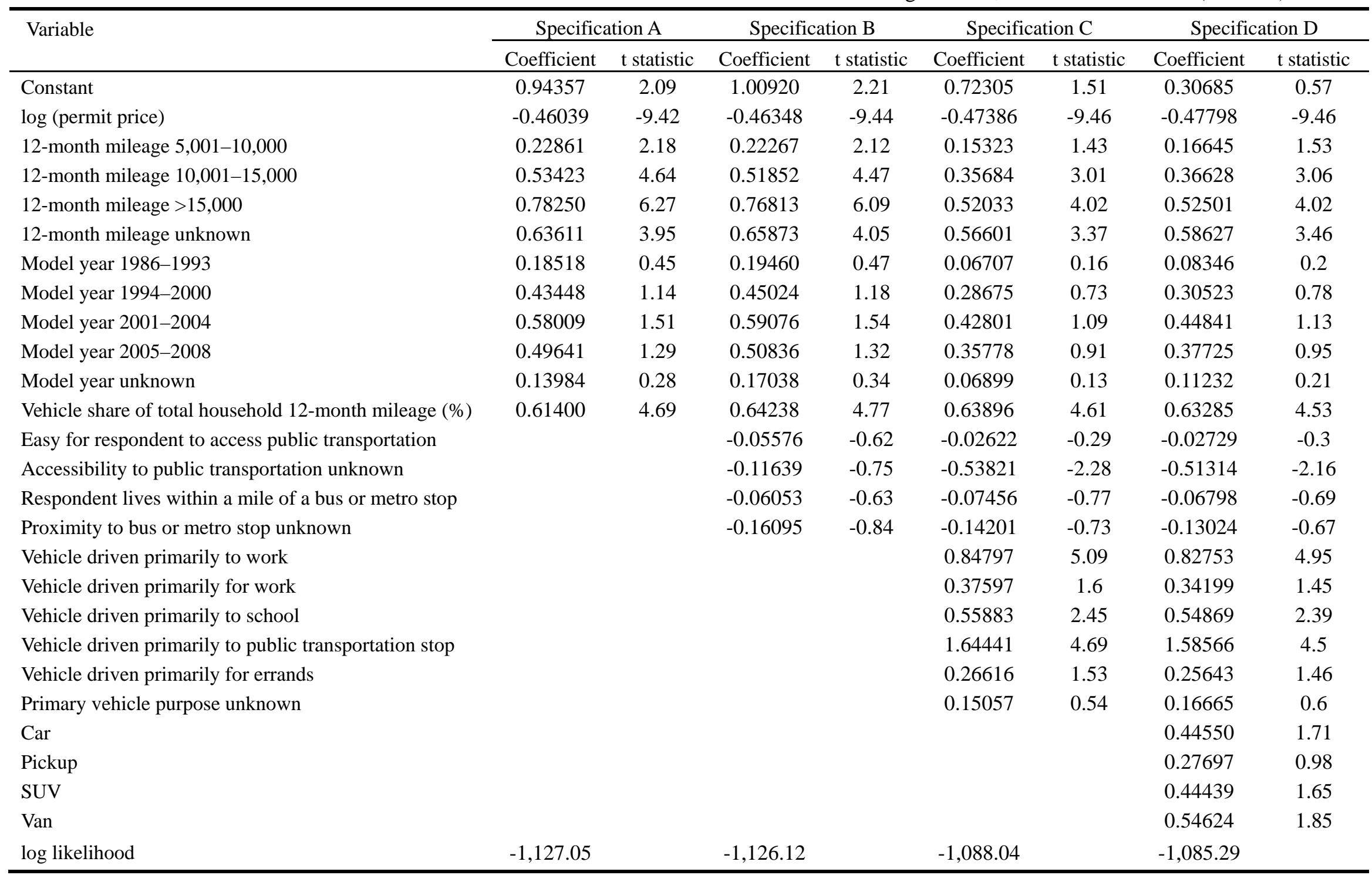

